\title{
Effects of Selective Withdrawal on Hydrodynamics of a Stratified Reservoir
}

\author{
Anıl Çalışkan • Şebnem Elçi
}

Received: 5 October 2007 / Accepted: 11 July 2008 /

Published online: 5 August 2008

(C) Springer Science + Business Media B.V. 2008

\begin{abstract}
In water supply reservoirs, selective withdrawal is commonly implemented to control released water temperature for quality purposes. This study investigated the effects of selective withdrawal on hydrodynamics of a stratified reservoir through numerical modeling and analytical analysis. A 3-D hydrodynamic model was applied where observations of water temperature time series recorded every $30 \mathrm{~min}$ at the thermocline and measured temperature profiles along the water column were used to validate the numerical model. The effect of selective withdrawal from four outlets located along the water intake structure of Tahtali Reservoir in Turkey on water temperatures was investigated and the effects on thermal stratification structure were discussed. Withdrawal of the water at the bottom outlet was found to be the most effective choice encouraging the mixing of the water column and thus reducing anoxia. The results of this study can be used to guide the further investigations in stratified lakes for better management practices.
\end{abstract}

Keywords Stratification • Hydrodynamics • EFDC • Tahtali Reservoir • Withdrawal effects • Outflow dynamics

\section{Introduction}

Sustainable management of water resources is crucial to maintain the needs of the living-beings. Under the risk of water scarcity that may be introduced by climate change, and contamination of resources by human intervention, management strategies are required to improve the quality of existing water supply reservoirs. Among various techniques used to enhance the water quality in reservoirs, selective

\footnotetext{
A. Çalışkan · Ş. Elçi $(\bowtie)$

Department of Civil Engineering, Izmir Institute of Technology, Urla, Izmir, Turkey e-mail: sebnemelci@iyte.edu.tr
}
A. Çalışkan
e-mail: anilcaliskan@iyte.edu.tr 
withdrawal is considered as the most effective means of controlling the quality of water released downstream. When water is released from hypolimnion in stratified reservoirs, anoxic water can result in poor water quality since it might contain dissolved iron, manganese, sulfide, ammonium and phosphate (Dortch 1997). The effect of selective withdrawal from various outlets on hydrodynamics and on stratification structure of the water column is further discussed in this paper. The study site is selected as Tahtali Reservoir in Turkey, a water supply reservoir, providing $40 \%$ of the water used in the city of Izmir (population: $~ 3.4$ million in 2000).

The complexities of the hydrodynamic processes in a reservoir suggest the use of numerical modeling approaches to provide a description of circulation, mixing and density stratification. Hydrodynamic models use reservoir geometry, inflows, withdrawals, and meteorological data to simulate water levels, flow velocities, and temperatures. In a reservoir, wind-generated surface stresses, buoyancy or density forcing, turbulent momentum and mass transport should all be simulated by the model. In this paper, a numerical hydrodynamic model is applied to Tahtali Reservoir to simulate temperature profiles due to atmospheric forcing and inflows/outflows, and results are compared to measured temperature data. A 3-D hydrodynamic model; Environmental Fluid Dynamics Code (EFDC) developed by Hamrick (1996) has been selected to model the hydrodynamics of Tahtali Reservoir.

The previous research studies on stratified lake hydrodynamics included investigation of stratification structure by nondimensional parameters and development of numerical schemes for heat transport and application of existing numerical models to water systems. Ottosson and Abrahamsson (1998) presented a numerical approach for simulation of heat transport in epilimnion (warmer upper layer) and hypolimnion (colder bottom layer) of the water column, which was later used as a sub-model in many models concerning lake ecosystems (Appelgren et al. 1996; Monte et al. 1997). Another study was carried out by Bell et al. (2006) in which one-dimensional twolayer lake model was used to simulate the daily temperature and oxygen profile of an lake in response to changes in wind, air temperature and radiation. The model has been tested over a 10-year period from 1991 to 1999 using daily weather data and fortnightly observations of chlorophyll a and secchi depth. The simulated and observed oxygen profiles were in reasonable agreement. Cesare et al. (2006) investigated the circulation in stratified lakes due to flood-induced turbidity currents. The impact of river born turbidity currents was investigated in Lake Lugano located on the border of Italy and Switzerland under varying conditions using data measured at the inflow river and inside the lake, together with a three-dimensional numerical model of the lake. In the research of Patterson et al. (1984), the vertical temperature and salinity structures of Wellington Reservoir (Western Australia) and Kootenay Lake (British Columbia) were simulated using field data and one-dimensional numerical model (DYRESM) with good results. They used nondimensional analysis (Wedderburn number), to assess the relative importance of surface stirring and shear production.

In previous studies on selective withdrawal of water from water intakes, the assumptions were that the effect of viscous forces on the flow is negligible, flow is steady and spherically symmetric (Imberger 1980; Wood 1968; Wood and Binney 1976). Craya (1949) first studied flow dynamics in a two-layered stratification suggesting Froude number to determine the critical discharge at which drawdown occurs (Anohin et al. 2006). Yih (1958) showed that at low Froude numbers, the withdrawal 
of water from stratified water column resulted in horizontal motion at the level of outlet. Pao and Kao (1974) discussed that shear waves are formed after opening of the outlet, and Imberger et al. (1976) expanded discussion to include the effect of vertical upstream boundary on shear wave behavior. Recent research summarizing the theory behind the outflow dynamics included studies by Ivey and Blake (1985), and Wood and Binney (1976) in which the flow regimes were discussed in terms of Froude number and defined transition number. Casamitjana et al. (2003) presented the effects of the water withdrawal level in stratification patterns of a reservoir by using 1-D lake model and showed that the thermocline occurred at the depth where water was withdrawn. In another study, Bonnet et al. (2000) stated that the vertical thermal structure clearly depended on the outlet level. Anohin et al. (2006) investigated the effect of internal waves on the hydrodynamics of the stratified fluid upon withdrawal of water from the outlets.

Many reservoirs, including Tahtali, are located along major river beds necessitating including the longitudinal gradients as well as vertical gradients in the analysis of hydrodynamics. Thus 1-D models are insufficient in this sense, and a 3-D hydrodynamic model was used in this study. Temperature profiles resulting from selective withdrawal at four different outlets located along the intake structure are modeled; and the best outlet level for water withdrawal encouraging mixing and thus improving water quality is discussed.

\section{Study Site}

The observations were conducted in Tahtali Reservoir (Fig. 1), Menderes, Turkey $\left(38^{\circ} 08^{\prime} \mathrm{N}, 27^{\circ} 06^{\prime} \mathrm{E}\right)$. Tahtali Dam was projected as a rockfill dam and completed in 1996 to supply fresh water to Izmir, the third largest metropolitan area with over 3 million population. The capacity of the dam is 175 million cubic meters and it generates monthly 5 million cubic meters water. The dam is currently operated by IZSU (Izmir Water and Sewage Administration).

Tahtali Reservoir has a surface area of $20 \mathrm{~km}^{2}$, a mean depth of $15 \mathrm{~m}$, with a maximum depth of $27 \mathrm{~m}$. The major inflows are from North via Sasal Stream and Tahtali Stream. Sasal Stream contributes 25\% whereas Tahtali Stream contributes $75 \%$ to the total inflow. The discharges of the other four streams are negligible. The withdrawal point is at Southwest location of the lake from the deepest area corresponding to $27 \mathrm{~m}$. The water is provided as drinking water for the city of Izmir after being treated. The retention time of the reservoir is 2.5 years calculated based on volume of the lake and outflow rate as compared to the retention times of 3 months in Villerest reservoir (Casamitjana et al. 2003), 191 years in Lake Superior, 2.6 years in Lake Erie, and 6 years in Lake Ontario (EPA 2006a).

The seasonal variation of water level, water withdrawal, evaporation and rainfall measured in 2006 are illustrated in Fig. 2. Stratification in the lake starts in April and decrease by the end of September. The water elevation has increased after rain events occurred in January, February and March. Water is generally withdrawn from hypolimnetic outlets with an average flow rate of $3 \mathrm{~m}^{3} / \mathrm{s}$. The site is exposed to the full force of wind blowing mostly from East as well as from North. The average annual wind speed is $3 \mathrm{~m} / \mathrm{s}$. The local has a Mediterranean climate, with average annual 


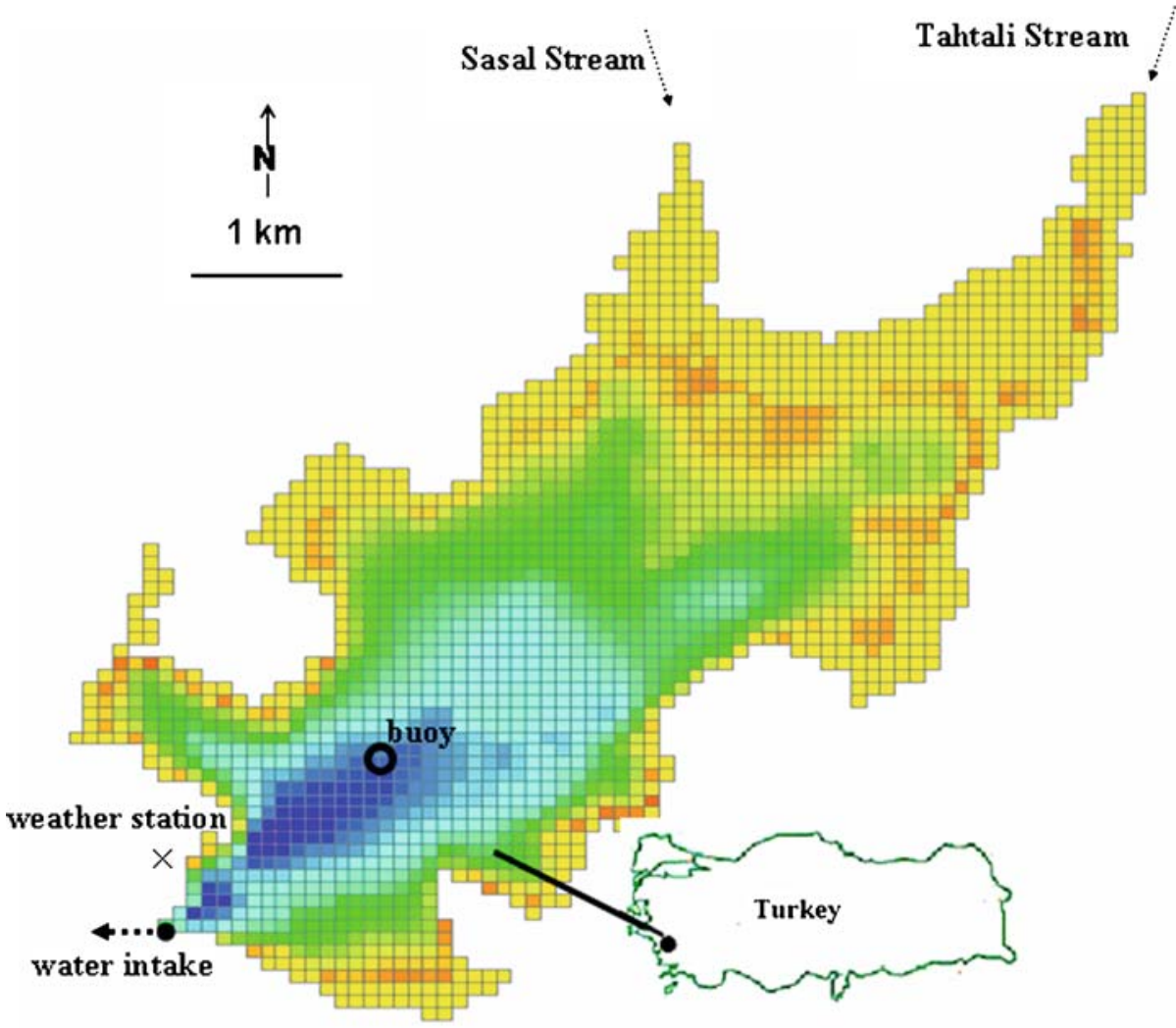

Fig. 1 Bathymetric map and the model grid of Tahtali Reservoir. The darker area represents the deepest region of the lake corresponding to $27 \mathrm{~m}$. Buoy, where stationary measurements were made, is shown by a circle

temperatures for the warmest month July at $28^{\circ} \mathrm{C}$ and for the coldest month January at $8^{\circ} \mathrm{C}$ (Fig. 3).

\section{Instrumentation}

The temperature profiles of the water column were measured by WQC-24 water quality meter designed by DKK-TOA. The instrument is capable of measuring water quality parameters ( $\mathrm{pH}$, conductivity, salinity, dissolved oxygen, turbidity, temperature), and a depth sensor is attached. Water quality data were recorded at $1 \mathrm{~m}$ intervals in vertical. Time series measurements of water temperature and water quality data were performed in July-August (dry season) and in SeptemberNovember (wet season) and data were recorded at 30 min intervals.

The meteorological data were acquired from the weather station records (every $30 \mathrm{~min}$ ) designed by TFA (Master Touch) installed at the Southwest location of Tahtali Reservoir. The data collected at this weather station included air pressure, 


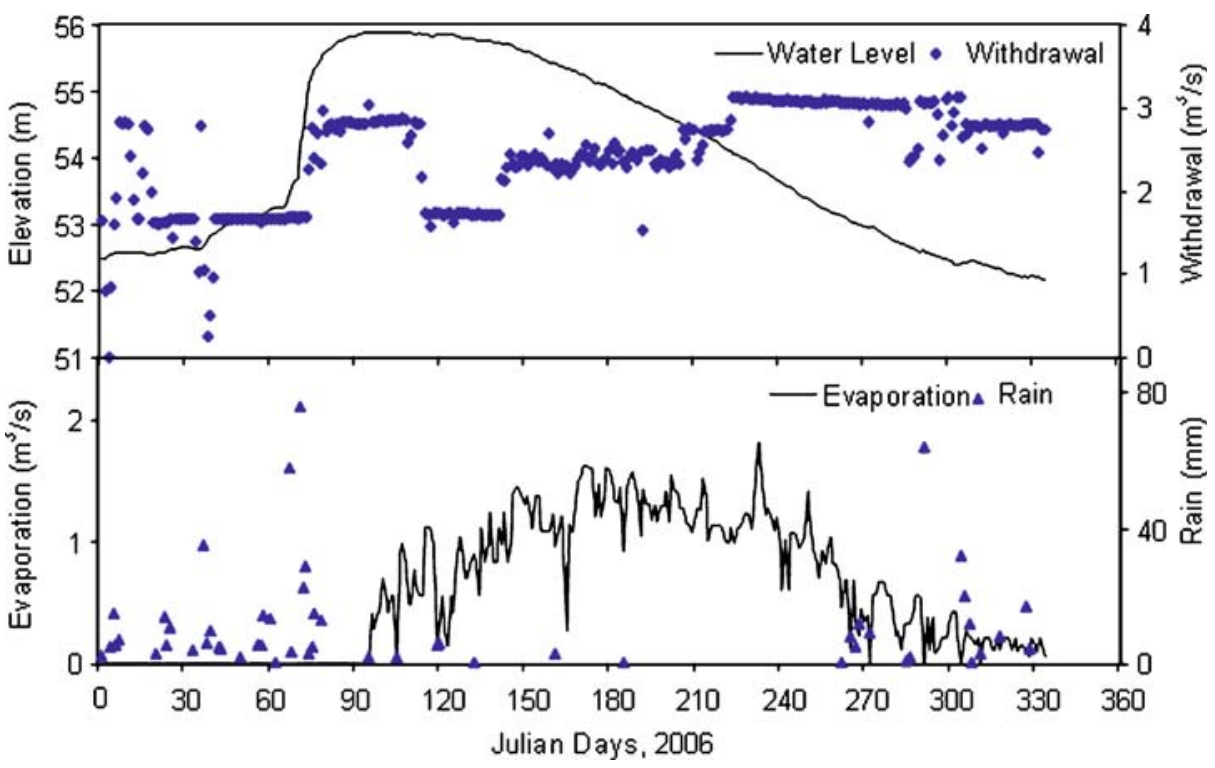

Fig. 2 Time series of water level, withdrawal, evaporation, and rainfall measured in Tahtali Reservoir during 2006

air temperature, humidity, solar radiation, wind speed, wind direction, rain and evaporation values (Fig. 4).

\section{Numerical Model}

In recent years, numerical models are widely used since the complexities of the hydrodynamic processes in a reservoir necessitate the use of numerical modeling approaches that provide accurate description of mixing within a water body.
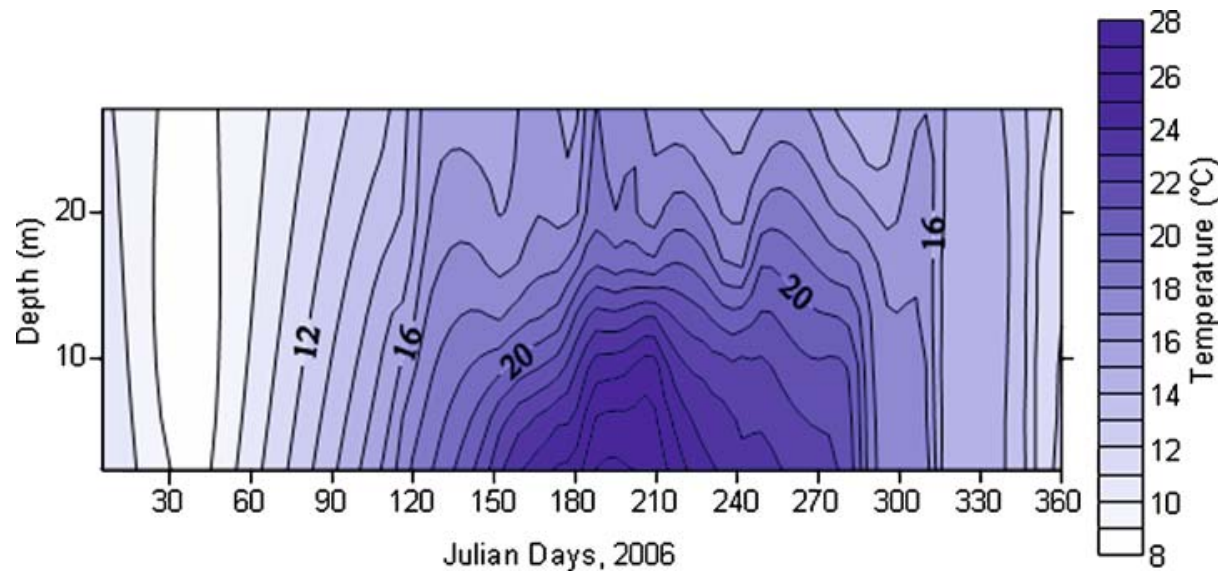

Fig. 3 Observed temperature profiles in Tahtali Reservoir during 2006 


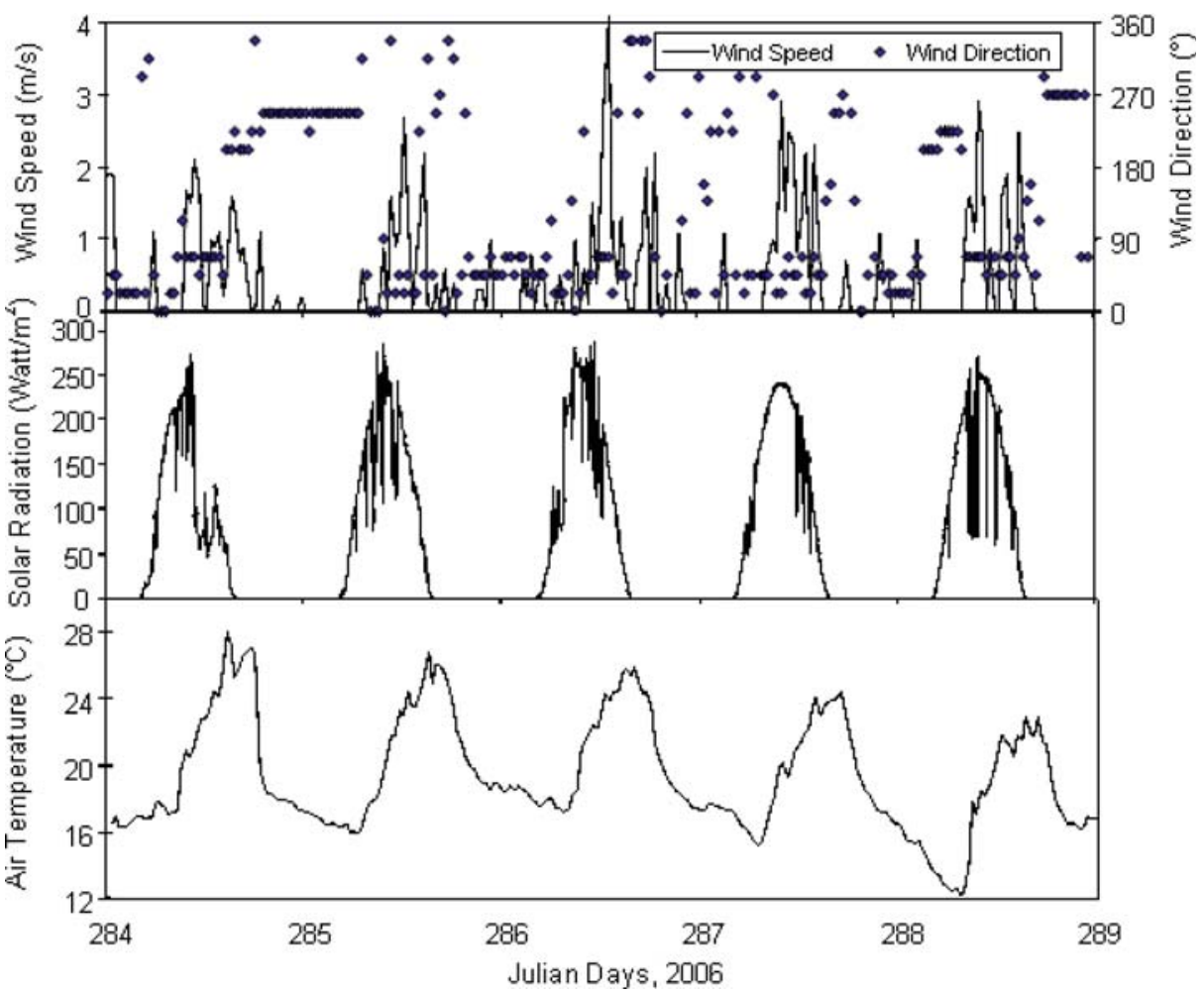

Fig. 4 Time series of wind, solar radiation and temperature data collected at the weather station in October, 2006

Numerical models can simulate different scenarios and cost less when compared to physical models.

In the present study, Environmental Fluid Dynamics Code, EFDC (version 1.0, release date: December, 2001), was used to model the hydrodynamic structure of Tahtali Reservoir. EFDC is a general-purpose modeling package for simulating three-dimensional (3-D) flow, transport, and biogeochemical processes in surface water systems (Hamrick 1996) such as rivers, lakes, reservoirs, estuaries, wetlands and coastal regions. The EFDC model was originally developed at Virginia Institute of Marine Science for estuarine and coastal applications. In addition to hydrodynamics, salinity, and temperature transport simulation capabilities, EFDC is capable of simulating cohesive and noncohesive sediment transport, near-field and far-field discharge dilution from multiple sources, the transport and fate of toxic contaminants in the water and sediment phases (EPA 2006b). The model uses finite difference scheme based on hydrostatic hydrodynamic equations and transport equations in vertical and horizontal coordinate systems which may be Cartesian or curvilinearorthogonal. Various finite difference numerical schemes are available for the solution of the equations. The model also can simulate wetting and drying conditions of the grid cells. For the details of model capabilities, the reader is referred to the user's manual (Hamrick 1996). 
Table 1 Dimensionless layer thickness of the simulated layers

\begin{tabular}{lllllllll}
\hline & \multicolumn{1}{l}{ Layer number } \\
\cline { 2 - 9 } & 1 & 2 & 3 & 4 & 5 & 6 & 7 \\
\hline Dimensionless layer thickness & 0.083 & 0.25 & 0.125 & 0.125 & 0.167 & 0.167 & 0.083 \\
\hline
\end{tabular}

The first layer number represents the bottom layer

The Tahtali hydrodynamic model grid contains 6,084 cells, 2,041 of which were active horizontal curvilinear grid cells with seven vertical layers. Trial and error approach was implemented for determining the time step used in the numerical solution that leads to a stable solution at the fastest time. A 10-s time step was used to insure numerical stability.

The horizontal discretization of each computational cell $\left(D_{x}, D_{y}\right)$ was $100 \mathrm{~m}$ on a side. The typical initial average water depth in each grid ranged from $1 \mathrm{~m}$ in the shallow region to $27 \mathrm{~m}$ in the deepest region. The dimensionless vertical layer thicknesses used in simulations are tabulated in Table 1 . The inflows were specified in the model by using the discharge data measured in Tahtali and Sasal Streams. The withdrawal data were provided by IZSU.

\section{Comparison of Numerical Modeling Results with Field Measurements}

Input data to the numerical model consisted of wind speed, wind direction, air temperature, solar radiation, evaporation, inflows and outflows. The initial conditions of the model were defined according to measurements implemented in the area, and the bathymetry of the lake was adapted to the current water level conditions at the time of the comparison.

Sensitivity analysis conducted to test the effect of different parameters on velocities and temperature profiles indicated that water velocities were strongly dominated by the wind data and correct measurement of the wind profile above lake surface is necessary for accurate prediction of velocities in the water column. The effect of inflows and outflows on the velocity profiles of Tahtali Reservoir was found insignificant. Another important parameter affecting simulated temperature values was solar radiation. The penetration of solar radiation through the water column is defined in Eq. 1 as;

$$
I_{z}=S R \times 0.5 \times \exp [-n z]
$$

where; $I_{z}$ is the downward solar irradiance; $S R$ is the short wave radiation; $n$ is the extinction coefficient. It was observed that when smaller value of $n$ is used the solar radiation penetrated further in the water column. A value of 0.5 was used as the extinction coefficient for Tahtali Reservoir model (Gal et al. 2003; Han et al. 2000) and solar radiation was allowed to penetrate until the thermocline.

The time series of temperature values were measured at $30 \mathrm{~min}$ intervals at $11 \mathrm{~m}$ depth below the water surface corresponding to the thermocline. Numerical simulations of temperature values were compared with field observations (Fig. 5). The water temperatures were highly affected by the cooling and warming air temperatures in August but the water temperatures in October did not show the same character due to the smaller daily variations of air temperature. High winds 

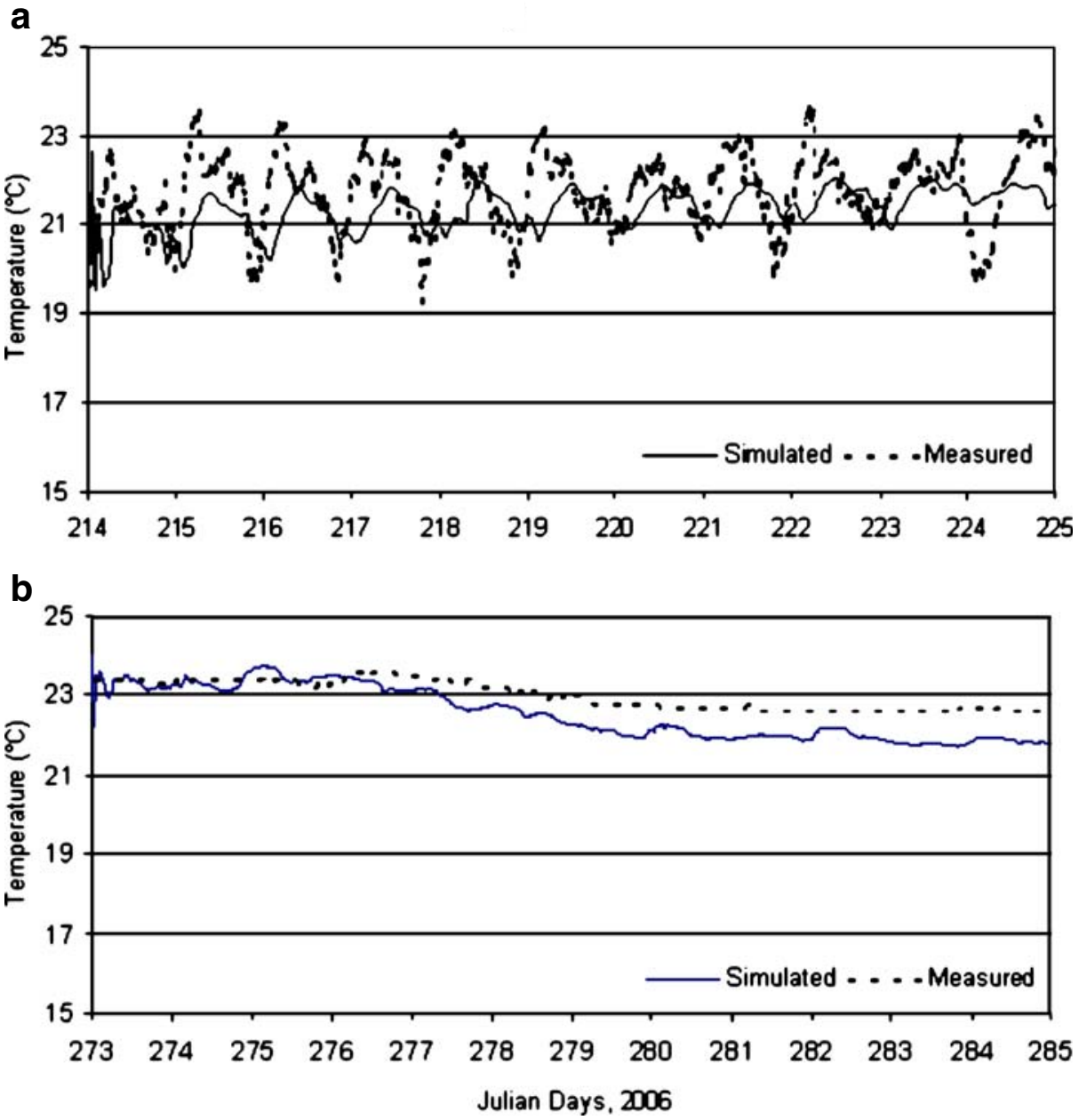

Fig. 5 Comparison of measured and modeled water temperatures at $11 \mathrm{~m}$ below the water surface at the buoy. (a) The measurement for August, 2006 and (b) for October, 2006

picking up mostly in the afternoon last for few hours and cease leading to internal seiches effective in the epilimnion and metalimnion. The daily variations of the temperatures are also attributed to these internal seiches having a period of approximately one day. This value is close to the period of basin scale internal wave calculated using the (Eq. 2) suggested by Imberger (1998).

$$
T=2 L \sqrt{\frac{\left(g^{\prime} \times h_{1} \times h_{2}\right)}{H}}
$$

where, $L$ is the length of the reservoir, $H$ is the total depth, $h_{1}$ and $h_{2}$ are the heights of the upper and lower layers. 
For the comparison of measured and simulated time series root-mean-square error (RMSE) was calculated by Eq. 3 .

$$
\mathrm{RMSE}=\left[\sum_{n=1}^{N} \frac{\left(T_{\text {est }}-T_{\mathrm{m}}\right)^{2}}{N}\right]^{1 / 2}
$$

where; $T_{\text {est }}$ is the modeled temperature profiles; $T_{\mathrm{m}}$ is the measured temperature profiles and $N$ is the number of data points. RMSE in August was calculated as 0.968 in degree Celsius whereas in October this value decreased to 0.571. These values are comparable with the other studies since Jin et al. (2000) reported RMSE of 0.7 for Lake Okeechobee and Rueda et al. (2003) reported RMSE of 0.414 and 0.608 in two different stations in Clear Lake.

\section{Stratification}

Temperature is the major controlling factor for the presence of stratification in lakes since it affects the hydrodynamics of lakes by forming density gradients in vertical. Large lakes or reservoirs are usually relatively stagnant and flow velocities are low when compared to rivers. Therefore, they often become stratified during the summer. In stratified lakes, metalimnion, the layer between the warmer upper layer (epilimnion) and the colder bottom layer (hypolimnion), behaves as a barrier between the top and the bottom layer and inhibits the mixing of these layers. As a result, some useful compounds such as dissolved oxygen can not be transported through the water column. The degree of stratification in Tahtali Reservoir was assessed through non-dimensional parameter analysis. Lake Number, $L_{\mathrm{N}}$ (Imberger 1998), an indicator for the degree of stability and mixing in the lake, was used for this analysis. $L_{\mathrm{N}}$ was calculated for the lake using the measured meteorological data and water temperatures relating with the conditions in August, October, and November 2006 by using the Eq. 4.

$$
L_{\mathrm{N}}=\left[S_{\mathrm{t}}\left(H-h_{\mathrm{T}}\right)\right] /\left[u_{*}^{2} A_{\mathrm{s}}^{3 / 2}\left(H-h_{\mathrm{v}}\right)\right]
$$

where; $S_{\mathrm{t}}$ is stability (Eq. 5); $u_{*}$ is the water shear velocity due to the wind (Eq. 6);

$$
\begin{gathered}
S_{\mathrm{t}}=\frac{1}{2} g^{\prime}\left[\left[\left(A_{1} A_{2} h_{1} h_{2}\right)\left(h_{1}+h_{2}\right)\right] /\left[\left(A_{1} h_{1}\right)+\left(A_{2} h_{2}\right)\right]\right] \\
u_{*}=\left[0.0013\left(\frac{\rho_{\mathrm{a}}}{\rho_{\mathrm{w}}}\right) U_{(10)}^{2}\right]^{1 / 2}
\end{gathered}
$$

where; $g^{\prime}$ is the reduced gravity (Eq. 7);

$$
g^{\prime}=\left(\frac{\Delta \rho}{\rho^{\prime}}\right) g
$$

where; $H$ is the total depth of the lake; $h_{\mathrm{T}}$ is the height from the bottom of the lake to the thermocline; $A_{\mathrm{s}}$ is the surface area of the lake; $h_{\mathrm{v}}$ is the height from the bed to the center of volume of the lake; $A_{1}, h_{1}$ is the area and the thickness of the upper layer; $A_{2}, h_{2}$ is the area and the thickness of the bottom layer; $\rho_{\mathrm{a}}$ is the density of air; 
$\rho_{\mathrm{w}}$ is the density of water; $U_{(10)}$ is the wind speed at $10 \mathrm{~m}$ above the water surface; $\Delta \rho$ is the density difference between the hypolimnion and the epilimnion; $\rho^{\prime}$ is the average density of the lake water; $g$ is the acceleration of gravity.

After solving the Eq. 4, $L_{\mathrm{N}}$ was calculated for the conditions in August, October, and November 2006. The critical value for stratification was found to be 3 based on water quality measurements as described in Elçi (2008). In this study, dissolved oxygen values recorded at the thermocline depth every 30 min experienced a sudden increase from 0 to $1.8 \mathrm{mg} / \mathrm{l}$ and continued to increase since the mixing of the water column had initiated. The wind speed corresponding to this value was calculated as $3 \mathrm{~m} / \mathrm{s}$ for Tahtali Reservoir. In August, $L_{\mathrm{N}}$ was smaller than the critical value $18 \%$ of the time, which indicates dense stratification in the lake. However, in October, this value increased to $33 \%$ and in November reached a value of $100 \%$ indicating that the lake was no more stratified beginning from November. In Lake Toolik, Alaska/USA, the lake was stable with $1 \mathrm{~m} / \mathrm{s}$ wind speed as it was in Tahtali Reservoir. However, the wind speed required for upwelling was $7 \mathrm{~m} / \mathrm{s}$ for Lake Toolik (MacIntyre et al. 2006). In another study on Lake Tahoe, the critical wind speed for upwelling was estimated $4 \mathrm{~m} / \mathrm{s}$ (Schladow and Thompson 2000). The critical value of $L_{\mathrm{N}}$ is reached in Lake Hartwell when the wind speed was $18 \mathrm{~m} / \mathrm{s}$, suggesting stronger stratification (Elçi et al. 2007).

Temperature profiles of the water column in Tahtali Reservoir were investigated by numerical modeling and monthly field measurements to analyze the structure of the stratification. Figure 6 depicts the measured temperature profiles of the water column that were used in the simulations. The stratification started at $10 \mathrm{~m}$ and approximately ended at $14 \mathrm{~m}$ depth in August. The temperature difference between the surface and the bottom layer was $12^{\circ} \mathrm{C}$. The temperature profile reached a uniform structure in November and the lake was well mixed at a temperature of $15^{\circ} \mathrm{C}$.

The effect of stratification on velocity profiles was investigated by numerical modeling (Fig. 7). The velocities decreased until the depth of thermocline (at $10 \mathrm{~m}$ )

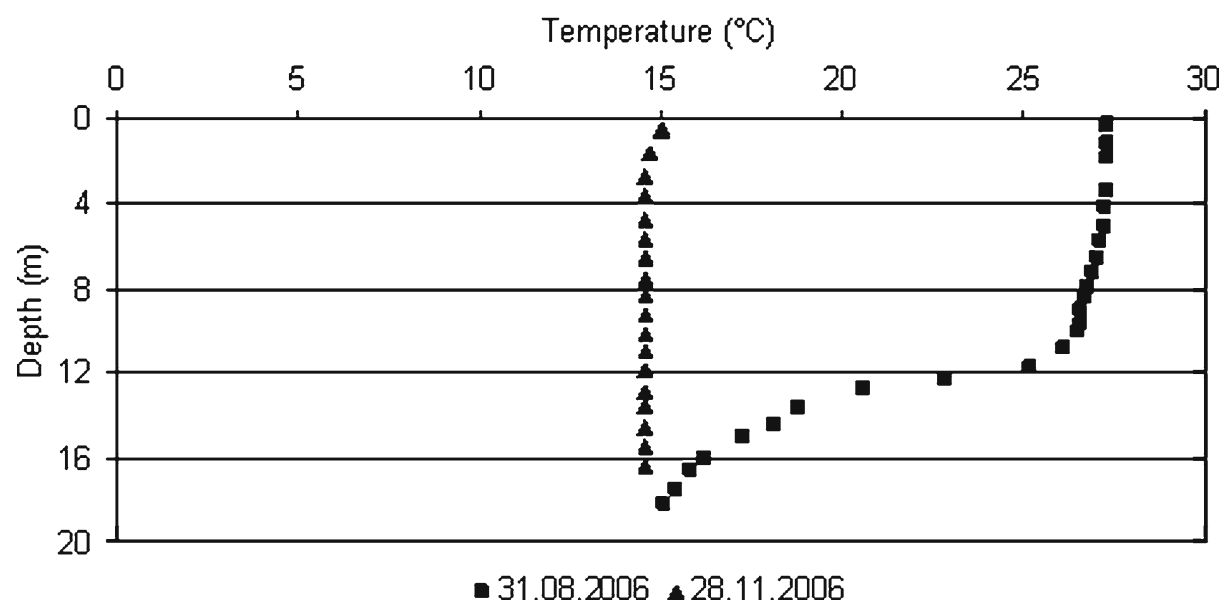

Fig. 6 Comparison of the measured temperature profiles of the water column in dry (July-August, 2006) and wet (September-November, 2006) seasons 
a

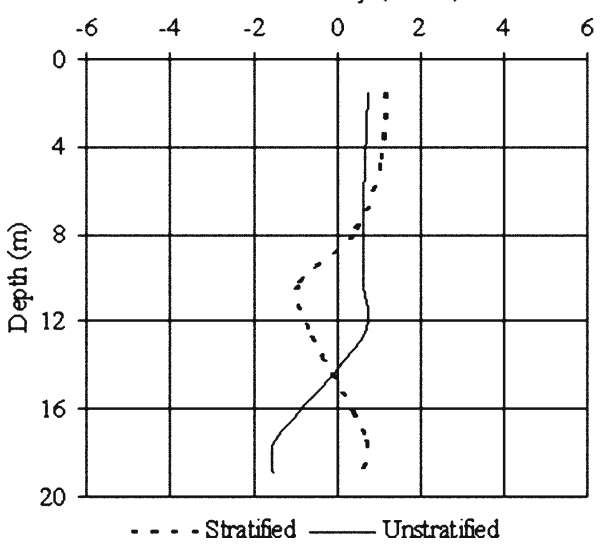

b

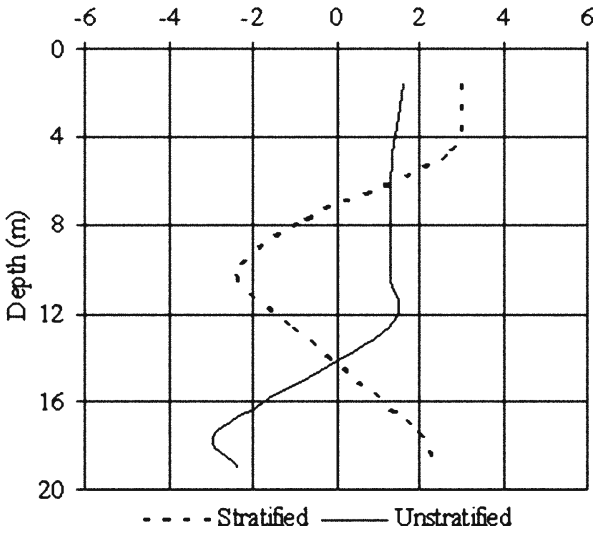

Fig. 7 Simulation of North (a) and East (b) velocities under stratified and unstratified conditions on 31.08.2006 at a cell

and changed direction after that depth. This points out that the thermocline behaved as a barrier which limited the mixing due to wind to upper layers of the water column and thus deepening of the warm layers could not be observed. In contrast, there was no significant change of the velocities under unstratified conditions until the depth of thermocline and then velocities changed direction as would be expected in a lake due to circulation.

\section{Withdrawal Effect}

In stratified lakes, the density gradient is most pronounced at thermocline, but there is also a weak temperature gradient throughout the hypolimnion, where the outlet structures of a reservoir are normally located. If water is withdrawn from such an outlet at small discharges, the vertical density gradient may produce buoyancy forces sufficiently strong to prohibit extensive vertical motions so that the water withdrawn comes from a thin horizontal layer at the level of the intake. At somewhat larger discharges the withdrawal layer may intersect the thermocline and at very large discharges the effects of buoyancy may be completely overwhelmed and the flow returns to potential flow (Fischer et al. 1979), where equipotential lines are perpendicular to streamlines which are tangent to the velocity vector of the flow. Following Ivey and Blake (1985) outflow dynamics at the outlets were investigated via transition number as defined in Eq. 8:

$$
S=\left(Q^{2} N v^{-3}\right)^{1 / 15}
$$

where; $S$ is the transition number; $Q$ is the total discharge; $N$ is the buoyancy frequency; $v$ is the kinematic viscosity. If $S>3$; the inertia-buoyancy regime governs the flow, forming a layer of constant thickness;

$$
\delta=C_{3}\left(Q N^{-1}\right)^{1 / 3}
$$


where; $C_{3}$ is the withdrawal coefficient and $C_{3}=1.42$ gave the best results for layer thickness $\Delta$ in inertia-buoyancy regime. $S$ was calculated as 15 for Tahtali Reservoir suggesting the strong buoyancy forces and that the water withdrawn comes from a thin horizontal layer at the level of the intake.

Wood and Binney (1976) examined lowering of upper water layer (drawdown) into a line sink positioned in the lower layer, suggesting the use of Froude number to define the critical discharge at which the drawdown occurs. Two cases may be defined for the radial flow. First, the outlet is close to the bottom of the lake (Eq. 10) and second, the outlet may be very much closer to the thermocline (Eq. 11).

$$
\begin{gathered}
F_{3 c}=\frac{Q_{3 c}}{\left[\left(\frac{\Delta \rho+\alpha^{2} \Delta^{1} \rho}{\rho_{0}}\right) g d^{5}\right]^{1 / 2}}=1.02 \quad d \approx(H-h) \\
F_{3 c}=2.04 d<<(H-h)
\end{gathered}
$$

where; $\Delta \rho$ is the density difference between the water at the surface and at the thermocline; $\alpha^{2}$ is the density jump coefficient; $\Delta^{1} \rho$ is the density difference between the water at the offtake and that at the top of the hypolimnion; $d$ is the distance between the center of the outlet and the layer interface. Wood (2001) summarized the existing theory for both line and point sink cases, showing that the ratio of discharges from a multiple-layered stratification is determined by the density difference between the layers, the location of a virtual control relative to the sink, and a total discharge at the valve.

In Tahtali Reservoir, there are four outlets located at different depths of the water intake structure (Fig. 8). The elevations of the outlets are 50, 43, 36 and $29 \mathrm{~m}$ respectively from the sea level. The water intake structure is reinforced concrete with a diameter of $17 \mathrm{~m}$ and $35 \mathrm{~m}$ height. The water withdrawn from one of these valves is pumped to the water treatment plant through two steel pipes with a diameter of

Fig. 8 Map of Tahtali Reservoir. Dashed box shows the model domain in which withdrawal effects were investigated. Circle shows the location of water intake

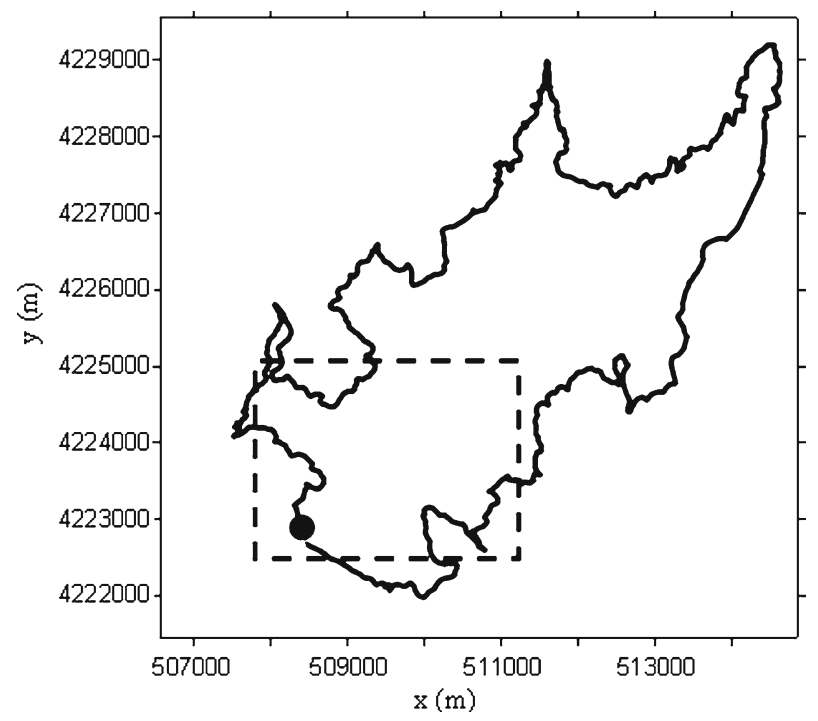


$1.6 \mathrm{~m}$. The critical discharge was calculated for three different outlets. The $43 \mathrm{~m}$ outlet level is the closest $(1.2 \mathrm{~m})$ to the thermocline point so by using the Eq. 11, the critical discharge for the outlet at $43 \mathrm{~m}$ was calculated as $0.15 \mathrm{~m}^{3} / \mathrm{s}$. For the other two outlets 36 and $29 \mathrm{~m}$, the critical discharges were calculated as 21 and $36 \mathrm{~m}^{3} / \mathrm{s}$ respectively using the Eq. 10 . According to this analysis, with an outflow rate of $3 \mathrm{~m}^{3} / \mathrm{s}$, the drawdown can only be observed when water is withdrawn from the outlet located above the thermocline.

The effect of withdrawal level on stratification patterns of the lake was investigated using EFDC model. The outlet at $43 \mathrm{~m}$ elevation was within the stratified region in the water column. The model runs were implemented one by one for all selective withdrawal levels to understand which outlet level would encourage mixing in the water column. The temperature differences simulated by the model when water was withdrawn from different outlets are shown in Fig. 9. When the water was withdrawn from the outlet located at $50 \mathrm{~m}$ from the sea level (Fig. 9a), the water temperatures in the mid-layer became $0.5 \%$ colder. When the withdrawal was from lower outlets (Fig. 9b, c, d), water temperatures in the stratified layer increased $0.5 \%$ at $43 \mathrm{~m}$ and $36 \mathrm{~m} ; 4 \%$ at $29 \mathrm{~m}$ indicating more mixing affecting the area within the

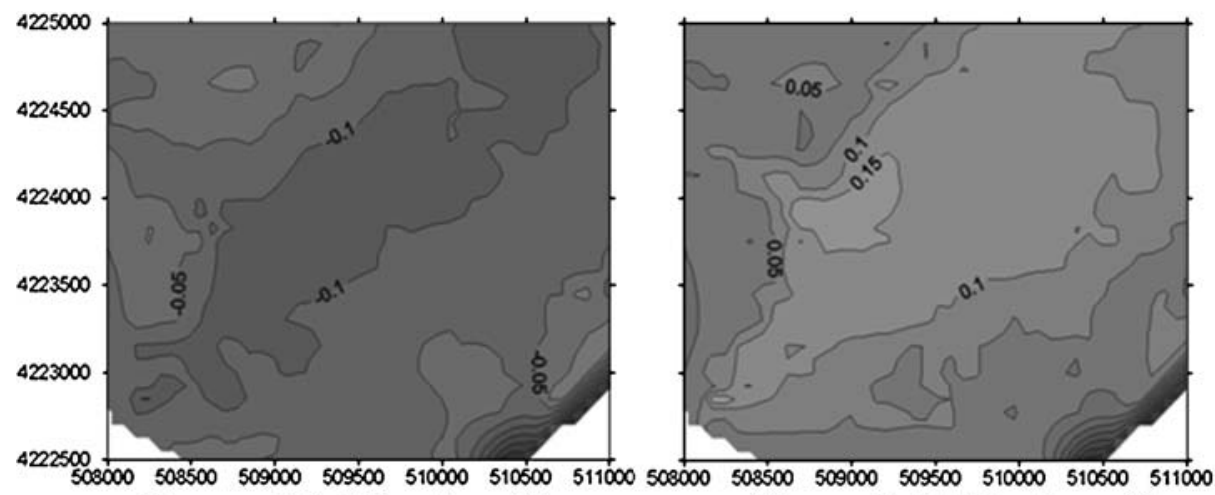

(a) Outlet Elevation $=50 \mathrm{~m}$.

(b) Outlet Elevation $=43 \mathrm{~m}$.

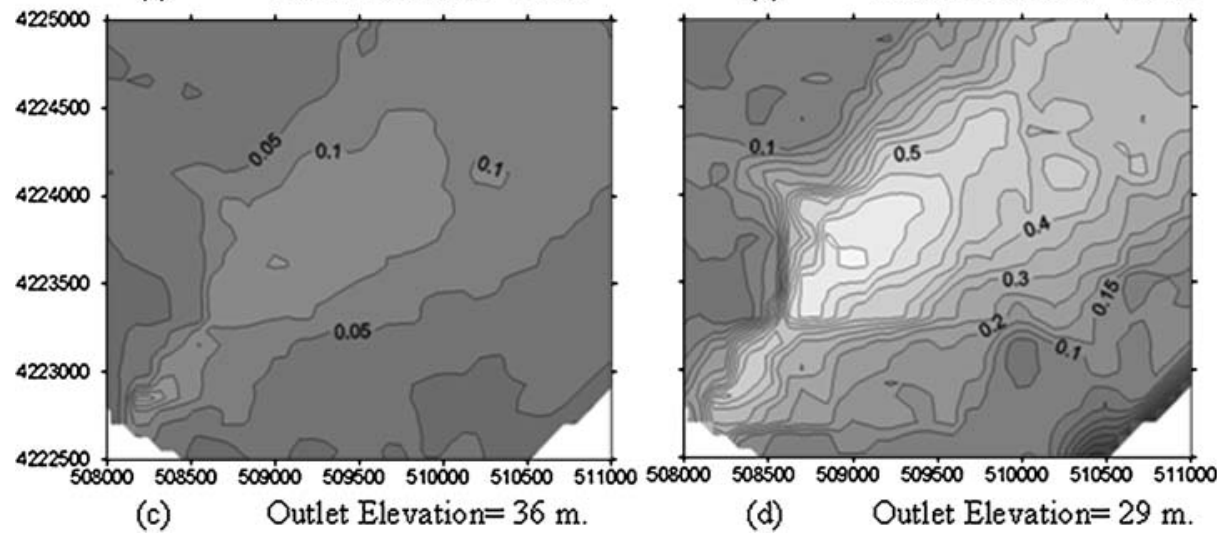

Fig. 9 Distribution of temperature differences between two models (before and after withdrawal) in the stratified layer $($ depth $=11 \mathrm{~m})$. The water level was $54 \mathrm{~m}$ during the simulation period in August. The withdrawal point is located at $x=508000 ; y=4222500$ 


\section{Temperature $\left({ }^{\circ} \mathrm{C}\right)$}

Temperature $\left({ }^{\circ} \mathrm{C}\right)$
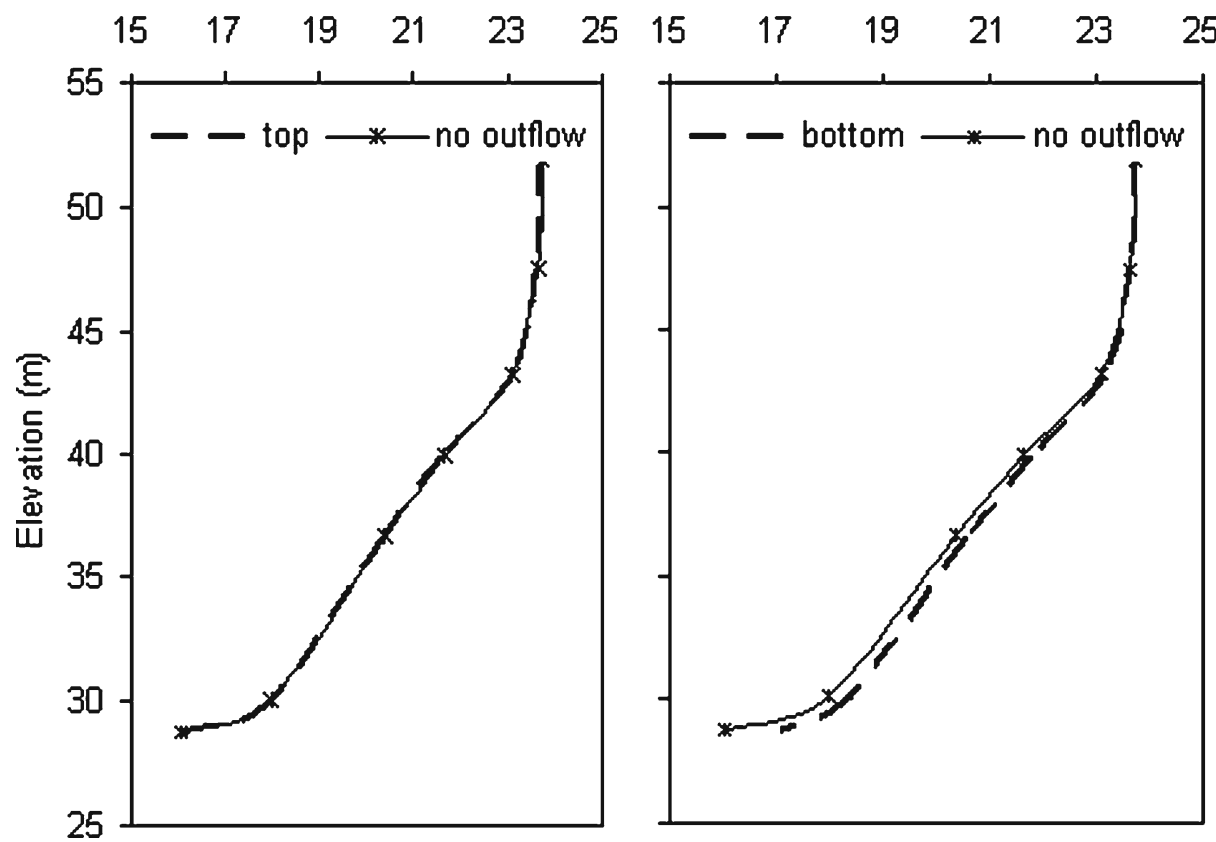

Fig. 10 Comparison of the withdrawal effect of the top (elevation $=50 \mathrm{~m}$ ), and the bottom outlet (elevation $=29 \mathrm{~m}$ ) with the model assumed that there was no outflow at the cell $300 \mathrm{~m}$ upstream of the withdrawal point

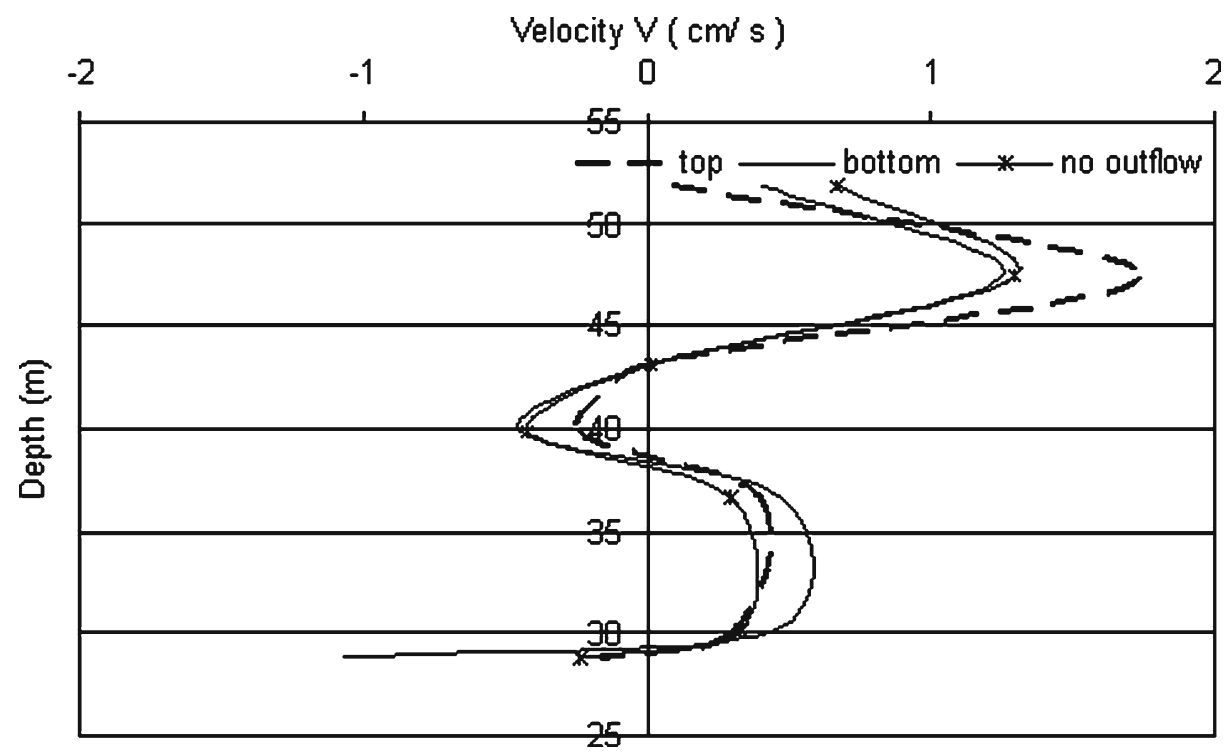

Fig. 11 Comparison of the withdrawal effect of the top (elevation $=50 \mathrm{~m}$ ), and the bottom outlet (elevation $=29 \mathrm{~m}$ ) with the model that there was no outflow at the cell $300 \mathrm{~m}$ upstream of the withdrawal point 
radius of $2 \mathrm{~km}$. When the temperature differences were plotted in vertical in a cell located $300 \mathrm{~m}$ away from the withdrawal point, water temperatures were decreased by $0.5 \%$ for the $50 \mathrm{~m}$ outlet. Withdrawing water from 43 and $36 \mathrm{~m}$ outlets increased the temperatures by $0.65 \%$. And when the outlet at $29 \mathrm{~m}$ was used, the temperature in hypolimnion increased up to $6 \%$ (Fig. 10). The 12 days simulations indicated that temperature increased in the stratified layer when the water was withdrawn below thermocline depth. These results indicate that withdrawal at the outlet located $29 \mathrm{~m}$ would enhance mixing in the water column.

In addition to the water temperature distribution, the effect of withdrawal on North velocities was compared in Fig. 11. The upper withdrawal increased the velocities in epilimnion by $34 \%$, whereas the lower withdrawal increased the velocities by $47 \%$ in hypolimnion validating the impact of withdrawal level.

\section{Conclusions}

This study has showed the effects of selective withdrawal on hydrodynamics of a stratified reservoir through numerical modeling and analytical analysis. The analysis was conducted using four outlets located along the water intake structure of Tahtali Reservoir in Turkey and the effects of withdrawal on thermal stratification structure were discussed.

The comparisons were made between the measured and simulated time series of temperature data at the thermocline. A three-dimensional numerical model, EFDC, was used to model the hydrodynamic structure of the reservoir. The numerical model results were harmonious with the measurements. The discrepancies between measured and modeled values (RMSE: 0.97 (August) and $0.57^{\circ} \mathrm{C}$ (October)) can be attributed to hydrostatic assumption used in the numerical model. Hydrostatic assumption, in which vertical accelerations are neglected, introduces artificial numerical diffusion of the density structure. The amplitudes of the internal waves observed in August were damped faster than the physical processes observed in the lake, indicating that EFDC is not capable of simulating internal waves.

Thermal stratification in the lake was analyzed through nondimensional analysis and numerical modeling. It was observed that, the velocities decreased and changed direction in proximity to the thermocline depth and increased after that point.

Selective withdrawal of water in reservoirs is commonly used to control the quality of water released. Numerical analysis based on different outlets indicated that withdrawing water from bottom outlet would likely lead to water quality enhancement within the lake. Withdrawing warmer water from epilimnion resulted in the preservation of the cooler water in hypolimnion whereas withdrawal from thermocline and hypolimnion caused warming of the hypolimnetic water, coinciding with the results obtained by Kennedy (1999). Since warming of the hypolimnion results in a decrease in the thermal stability of the water column, decreased stability can promote vertical entrainment of nutrients in the epilimnion (Effler et al. 1986). In Tahtali Reservoir, the hypolimnetic water became warmer when the water was extracted beneath the level of the thermocline.

The results of this study will also guide the further investigations in Tahtali Reservoir including modeling of water quality and sediment transport. Among various water quality management techniques summarized in the literature for artificial destratification (Dortch 1997), it is recommended to use hydraulic destratification 
in Tahtali, using small diameter diff user ports to create high velocity water jets. This type of treatment would mix hypolimnetic and epilimnetic water which in turn should prevent anoxia.

Acknowledgements Funding for this study is provided by European Union (Project \# 28292) and Tubitak (Project \# 104Y323). We also would like to thank Ramazan Aydin who contributed to the field measurements. We are grateful to the staff of Izmir Water and Sewage Administration (IZSU) for their helps during the measurements and for providing us the boat.

\section{References}

Anohin VV, Imberger J, Romero J, Ivey GN (2006) Effect of long internal waves on the quality of water withdrawn from a stratified reservoir. J Hydraul Eng 132(11):1134. doi:10.1061/(ASCE)0733-9429(2006)132:11(1134)

Appelgren A, Bergstrom U, Brittain J, Gallego Diaz E, Hakanson L, Heling R, et al (1996) An outline of a model-based expert system to identify optimal remedial strategies for restoring contaminated aquatic ecosystems. The project MOIRA. ENEA, Report RT/AMB/96/17

Bell VA, George DG, Moore RJ, Parker J (2006) Using a 1-D mixing model to simulate the vertical flux of heat and oxygen in a lake subject to episodic mixing. Ecol Model 190:41-54. doi:10.1016/j.ecolmodel.2005.02.025

Bonnet M, Poulin M, Devaux J (2000) Numerical modeling of thermal stratification in a lake reservoir. Methodology and case study. Aquat Sci 62:105-124. doi:10.1007/s000270050001

Casamitjana X, Serra T, Colomer J, Baserba C, Pérez-Losada J (2003) Effects of the water withdrawal in the stratification patterns of a reservoir. Hydrobiologia 504:21-28. doi:10.1023/B:HYDR.0000008504.61773.77

Craya A (1949) Recherches theoriques sur l' ecoulement de couches superposees de fluides de densites dierentes. Houille Blanche 4:44-55

Cesare GD, Boillat JL, Schleiss J (2006) Circulation in stratified lakes due to flood-induced turbidity currents. J Environ Eng 132:11 (1508)

Dortch MS (1997) Water quality considerations in reservoir management. Water Resources Update, Universities Council on Water Resources, Southern Illinois, University Carbondale, IL

Effler SW, Wodka MC, Driscoll CT, Brooks C, Perkins M, Owens EM (1986) Entrainment base flux of phosphorus in Onondaga Lake. J Environ Eng 112:617-622

Elçi Ş (2008) Effects of thermal stratification and mixing on reservoir water quality. Limnology 9(2):135-142

Elçi Ş, Work PA, Hayter EJ (2007) Influence of stratification and shoreline erosion on reservoir sedimentation patterns. J Hydraul Eng 133(3):255-266. doi:10.1061/(ASCE)07339429(2007)133:3(255)

EPA (2006a) Great lakes. http://www.epa.gov/glnpo/basicinfo.html

EPA (2006b) Environmental fluid dynamics code. http://www.epa.gov/ATHENS/wwqtsc/html/ efdc.html

Fischer HB, List EJ, Koh RCY, Imberger J, Brooks NH (1979) Mixing in inland and coastal waters. Academic, New York

Gal G, Imberger J, Zohary T, Antenucci J, Anis A, Rosenberg T (2003) Simulating the thermal dynamics of Lake Kinneret. Ecol Model 162(1):69-86. doi:10.1016/S0304-3800(02)00380-0

Hamrick JM (1996) Users manual for the environmental fluid dynamic computer code. The college of William and Mary, Virginia Institute of Marine Science, Special Report 328, 224 pp

Han BP, Armengol J, Carlos Garcia J, Comerma M, Roura M, Dolz J, et al (2000) The thermal structure of Sau Reservoir (NE: Spain): a simulation approach. Ecol Model 125(2):109-122. doi:10.1016/S0304-3800(99)00176-3

Imberger J (1980) Selective withdrawal: a review. Second Int Symp. Stratifed Flows The Nor Inst Technol Trondheim Nor 1:381-400

Imberger J (1998) Flux paths in a stratified lake: a review. In: Imberger J (ed) Physical processes in lakes and oceans, vol 54. American Geophysical Union, Washington, DC, pp 1-18

Imberger J, Thompson RO, Fandry C (1976) Selective withdrawal from a finite rectangular tank. J Fluid Mech 78(3):489-512. doi:10.1017/S0022112076002577

Ivey GN, Blake S (1985) Axisymetric withdrawal and inflow in a density-stratified container. J Fluid Mech 161:115-137. doi:10.1017/S0022112085002841 
Jin KR, Hamrick JH, Tisdale $\mathrm{T}$ (2000) Application of three-dimensional hydrodynamic model for Lake Okeechobee. J Hydraul Eng 126(10):758-771. doi:10.1061/(ASCE)07339429(2000)126:10(758)

Kennedy RH (1999) Reservoir design and operation: limnological implications and management opportunities. In: Tundisi JG, Straskraba M (eds) Theoretical reservoir ecology and its applications. Backhuys, Leiden, pp 1-28

MacIntyre S, James OS, Sarah AG, George WK (2006) Physical pathways of nutrient supply in a small, ultraoligotrophic arctic lake during summer stratification. Limnol Oceanogr 51(2):11071124

Monte L, Hakanson L, Brittain J (1997) Prototype models for the MOIRA computerized system. ENEA, Report, RT/AMB/97/5

Ottosson F, Abrahamsson O (1998) Presentation and analysis of a model simulating epilimnetic and hypolimnetic temperatures in lakes. Ecol Model 110:26

Pao HP, Kao TW (1974) Dynamics of establishment of selective withdrawal of a stratified fluid from a line sink. Part I: theory. Ishikawajima-Harima Eng Rev 65:657-688

Patterson JC, Hamblin PF, Imberger J (1984) Classification and dynamic simulation of the vertical density structure of lakes. Limnol Oceanogr 29(4):845-861

Rueda FJ, Schladow SG, Monismith SG, Stacey MT (2003) Dynamics of large polymictic lake. I. Field observations. J Hydraul Eng 129(2):82-91. doi:10.1061/(ASCE)0733-9429(2003)129:2(82)

Schladow SG, Thompson KL (2000) Winter thermal structure of Lake Tahoe. Limnology and oceanography. American Chemical Society, Washington

Wood IR (1968) Selective withdrawal from stable stratified fluid. J Fluid Mech 32:209-223. doi:10.1017/S0022112068000686

Wood IR (2001) Extensions to the theory of selective withdrawal. J Fluid Mech 448:315-333. doi:10.1017/S002211200100605X

Wood IR, Binney P (1976) Selective withdrawal from a two-layered fluid. Research Rep., Department of Civil Engineering, Univ. of Canterbury, Christchurch, New Zealand

Yih CS (1958) On the flow of a stratified fluid. In: Proc., 3rd U.S. National Congress of Applied Mechanics, pp 857-861 